\title{
The Enlightenment of Moral Education Thought in The Analects of Confucius to Friendly Education for College Students
}

\author{
Lu Yali \\ China Jiliang University \\ Hangzhou, China
}

\begin{abstract}
Friendly education has gradually attracted attention of university campuses in recent years. From Confucianism to Taoism, there has been a detailed account of friendship. Confucianism and Taoism regard friendship and mutual assistance as the benchmark, emphasizing individual attention and valuing social justice. The Analects of Confucius has had a profound influence on Chinese culture, and the moral education thought contained therein is also in line with the requirements of socialist core values. This paper tries to explore the moral education thoughts contained in the Analects of Confucius in three aspects, including extracting its essence, eliminating outdated views, and linking it with the friendly education for college students. The purpose is to enable college students to gain inspiration for friendship in reading classics.
\end{abstract}

Keywords-The Analects of Confucius; Moral education; friendly; College students

\section{INTRODUCTION}

Friendliness means intimacy and friendship, harmony between people, warm and easy-going attitude, and like to communicate with others. The word "friendly" is also one of the socialist core values put forward by the party's 18th National Congress. Friendliness plays an important role in maintaining a harmonious relationship between people. From Confucianism to Taoism, there has been a detailed account of friendship. Confucianism and Taoism have used friendship and mutual assistance as the benchmark, emphasizing individual attention and taking social justice [1-2].

\section{A BRIEF INTRODUCTION TO THE ANALECTS OF CONFUCIUS}

The Analects of Confucius is generally considered to have been compiled by Confucius disciples and re-disciplined disciples. The compilation time was shortly after the death of Confucius. The book of The Analects of the Warring States period marked the beginning of private books in China. At the end of the Western Han Dynasty, Zhang Wei wrote the latest version of The Analects, which was quite influential at the time. In the post-Song Dynasty Zhu Xi's "The Four Books Collection Notes"(in Chinese), the "Analects of the Analects of Confucius"(in Chinese) became one of the standards of the imperial examinations at that time, and it is still quite influential. The current version of the Analects of Confucius version is 20 chapters. Each article draws two or three words from the first sentence of the article. The book
"The Analects of Confucius" is written in quotations and has a wide range of contents. The ideas it contains are profound and profound, and have influenced China and the world culture for more than two thousand years. The Analects of Confucius has had a profound influence on Chinese culture, and the moral education thought contained therein is also in line with the requirements of the socialist core values. It is of great significance to dig deeper into the friendly thoughts contained in The Analects [3-4], to extract its essence, to remove the dross, and to apply the "The Analects of Confucius" moral education to college students' education. To strengthen the cultivation of the friendly concept of contemporary college students, we must proceed from the basic situation of modern students, and also enter the long-standing traditional culture of our country to carry forward and develop our fine traditions and virtues.

\section{AN OVERVIEW OF THE MORAL EDUCATION THOUGHTS IN THE ANALECTS}

The core concept of moral education in The Analects is five aspects: benevolence, righteousness, propriety, wisdom, and sincerity. The meaning of "benevolence" in The Analects is very rich. Confucius puts "aspiration for the Tao, according to the virtue, according to the benevolence, and travels to the arts" As the general outline of the doctrine of thought. It is also the fundamental basis of Chinese ethics [5-6].

The meaning of "benevolence" is "love". Confucius advocated respect, friendliness and sympathy for the masses of ordinary people, including ordinary workers, on the premise of maintaining the ranks. He praised "a man extensively conferring benefits on the people," Ask the ruler to "use and love, and make the people take time." At the same time, his disciples are required to " overflow in love to all" ("The Analects of Confucius").

The traditional interpretation of "righteousness" is appropriate and requires people to follow a reasonable living principle. People's view of justice and interests is reflected in their values, moral literacy, and ideal pursuit. Confucius said that "The mind of the superior man is conversant with righteousness; the mind of the mean man is conversant with gain"; "The superior man thinks of virtue; the small man thinks of comfort. The superior man thinks of the sanctions of law; the small man thinks of favors which he may receive" ("The Analects of Confucius"). The criteria for Confucius to 
distinguish between a gentleman and a villain are "profit" and "righteousness." Confucius believes that a straightforward gentleman is fair and friendly, and has certain rules for everything. There is no difference between far and near and close.

Propriety is an external norm that sustains the human community. The ceremony was originally a ceremony rule for Xia, Shang and Zhou dynasties, covering ceremonial systems and ethics. In a society full of turmoil, Confucius put the normative principles of ethics and morality and the institutional ideals of civilized society in the "propriety". Therefore, his "propriety" is not a simple retro, to explain his own ideals about society and politics. Confucius believes that " $t$ ' If you do not learn the rules of Propriety, your character cannot be established", "'If you do not know the rules of Propriety, your character cannot be established.", "the people are born, the ritual is important" ("Book of Propriety, Apocalypse"). Confucius not only attaches importance to rituals, but also emphasizes lead by example and practice. First of all, he is "just in his own body" and can be "positive person". "Their being right, not doing it; its not correct, though not making it" ("The Analects of Confucius" ). Confucius not only insisted on his own rituals, but also taught his disciples. "Confucius went to Cao Shisong and the disciples under the big tree" "Historical Records Confucius Family", which is about the story of Confucius's rituals.

Wisdom, that is, wise. Confucius: "A wise man is not perplexed, a kind man is not worried, and a brave man is not afraid." Confucius put together wisdom and "benevolence" and "brave" to discuss. I believe that good personality cultivation must have three points: wisdom, bravery, and virtue. Wisdom is an important aid to magnanimity and brave. But in Confucius's view, the wisdom is in "personnel," that is, focusing on analyzing and identifying the complex phenomena of society. Fan Chi asked benevolence, Confucius: "Love people." Asked wisdom, Confucius:: "Know people." Fan Chi did not reach, Confucius: "Take straight mistakes, can make the shackles straight" ("The Analects of Confucius Yan Yuan") . Here, Confucius said that "knowing people" is also a manifestation of wisdom, which means understanding the wisdom of people. People who choose both ability and political integrity are people-oriented, do their best and make the best use of them, and society can prosper.

Sincerity, that is integrity, is one of the important concepts of traditional Confucian morality and one of the good qualities of the Chinese nation. Confucius: "If a gentleman is not heavy, then he is not arrogant, but his studies are not solid. The Lord is faithful. No friend is not as good as himself. If you do not tamper with it" ("The Analects of Confucius"). The faithfulness mentioned by Confucius is not a unilateral standard, but includes honesty and trustworthiness, loyalty and perseverance, love of learning, and correcting mistakes. Confucius said "My three provinces are my own: whether, in transacting business for others, I may have been not faithful; whether, in intercourse with friends, I may have been not sincere; whether I may have not mastered and practiced the instructions of my teacher." ("The Analects of Confucius"). If Confucius is a strong man, he must first look at himself, proceed from himself, and pay attention to his inner moral cultivation. Its "loyalty" and "belief" thoughts reflect a person's self-reflection ability. Only when a person has good reflective ability can he put himself in the shoes of others to think about others, do his loyalty, and keep his promise.

The Analects of Confucius records a lot of friendly expressions of "benevolence, righteousness, propriety, wisdom, sincerity" in social interaction. For example, "The Analects of Confucius " says that "In practicing the rules of propriety, a natural ease is to be prized. In the ways prescribed by the ancient kings, this is the excellent quality, and in things small and great we follow them" In the first sentence, Confucius showed that the utility of etiquette is more expensive than harmony. And is the ethical, political, and social principles that Confucianism particularly advocates. In Yang Yufu's "The Analects of Confucius", he wrote: "In the event, all of them are in the middle, and they are not alone in the anger and sorrow.". It is appropriate to say this with words, and the words are just right." It can be seen that the thought of "harmony is expensive" in the Analects of Confucius is indeed one of the standards of society at that time. Although the idea of "harmony is expensive" in feudal society is to ease the opposition class. The contradiction between them has reached the goal of stabilizing social order at that time. However, the friendly attitude of communication has always been advocated by the society. "Harmony is not only applicable to family relations, but also to social relations. It is best to be kind to others.

\section{THE NECESSITY OF FRIENDLY EDUCATION}

In recent years, the problem of moral education for college students has gradually been exposed, and it can be said that it has constituted a common problem in contemporary society. Confucius: "Now the man of perfect virtue, wishing to be established himself, seeks also to establish others; wishing to be enlarged himself, he seeks also to enlarge others" ("The Analects of Confucius"). The lover's thought expressed in this is a kind of loyalty and morality that respects each other, cares for each other, and treats others with kindness. However, most college students nowadays are born out of a single-child family. From birth to adulthood, they are all prepared by many elders in the family. This has led some college students to lack a kind and friendly view, which makes some college students easy to be self-centered. They only consider their own interests when interacting with others. They only do things for themselves, never consider others, and lack social contribution. spirit. As a result, more and more schools are integrating friendship into campus culture. The campus culture is three-dimensional and transparent, and contains many conditions, such as material conditions and human conditions. Campus culture is both an environment and an atmosphere. An educational atmosphere that requires us to be patiently trained and carefully managed. Young students are the future and hope of the motherland. Establishing the values of college students' friendship is not only helpful to the establishment of university moral education, but also to the development of students and the realization of self-worth. Therefore, families, schools, and societies should unite to create a good environment, strengthen public welfare practices, and follow the training standards to promote the formation of young students. 
The unity of school, family and society is the foundation of school moral education. College students are at an important stage of leaving the campus, entering the society and embarking on a job. Although their outlook on life, values, and world outlook are basically qualitative, there is still room for improvement. They have good plasticity in moral education. Therefore, in the school moral education work, we must exert the role of friendly moral education and strive to improve the character of students. Character education is what we call moral education. It is based on the background of contemporary society's structural changes, globalization and economic diversification. It studies how to make school moral education train students to respect tradition and establish correct value orientation, and cultivate educated people. Virtue.

\section{Moral Education Thought IN THE ANalects of CONFUCIUS AND FRIENDLY EDUCATION FOR COLLEGE STUDENTS}

While guiding the moral education of college students, we can carry out moral education with wisdom, sincerity, good interests and ethics as moral standards. According to Confucius's idea of teaching students according to their aptitude, according to the personal situation of each college student, they should make up for each other and strive for each student to achieve self and contribute to society. Benevolence is an important category in traditional social ethics. The thought of benevolence requires us to maintain a friendly attitude, love the country, love our parents and elders, love classmates, love ourselves, and love life. Be caring for others, caring for the collective, learning what you don't want, don't do it to others. The relationship between benefit and righteousness is an important issue that Confucian scholars have been discussing for thousands of years. For college students, it is very important to correctly handle the relationship between "righteousness" and pursuit of "righteousness". It is related to people, people and collectives, people and society. The relationship between justice and profit is actually the relationship between spiritual morality and material pursuit. There should be a dialectical unity between them. Therefore, we must train college students to be a person who uses ideals to distinguish between right and wrong but has sincere emotions. This requires college students to adhere to the truth, strengthen their convictions, strive to achieve personal ideals, and combine personal ideals with social ideals. In addition, treating people with courtesy is also an important inspiration for the Analects of Confucius on the friendly education of college students. "Benevolence" is the core idea of Confucianism, and "propriety" is an external code of public behavior. Confucius: "To subdue one's self and return to propriety, is perfect virtue" ("The Analects of Confucius"). Confucius believes that benevolence is the inner essence of ritual, and the kindness and respectful ritual is the external manifestation of benevolence. These performances are very conducive to shaping people's good quality of people-oriented, respectful, sincere and sincere. The use of wisdom is also a highlight in The Analects. Confucius believes that "intelligence" is not only smart and intelligent, hardworking and eager to learn, but also to make yourself more wise through learning. This requires that college students, while full of wisdom, must learn to use reason to look at problems and to distinguish between right and wrong. Combine quality cultivation with reason. At the same time, Confucianism advocates that people behave in a consistent manner and abide by integrity. Integrity is the traditional virtue of the Chinese nation and an important embodiment of friendship in social interaction. This requires that our contemporary college students must be committed to integrity and words.

At present, China's economic level and scientific and technological level are developing rapidly, and our society is also in a critical period of transformation. People's lifestyles and values are also quietly changing. In such an environment, college students face some moral confusion in the face of society and campus. Once college students choose to follow the path of morality in the face of pressure difficulties, the consequences will be unimaginable. Therefore, we should vigorously promote friendly education into the campus. This is not only an inheritance of the fine traditions of the Chinese nation, but also an effective way to achieve high-quality moral education for college students. Friendly education requires educators to educate the educated students through the cultivation of theoretical and practical practices, and to enable educators to gradually adapt to the social environment and meet the social requirements for ideology and morality. This makes the friendly moral education have the characteristics of slowness, reality, long-term, and permeability. Analysis of the influential factors of college students' friendly values education is not only related to the achievement of the goal of college students' moral education, but also to the future development of students and the realization of self-worth.

\section{CONCLUSION}

To sum up, a new generation of college students in today's society should draw on the high-quality moral education concept from the traditional classics such as The Analects, strengthen friendly education, standardize their own morality, and establish an excellent national quality vane for the motherland.

\section{REFERENCES}

[1] Liu Dejiang. The Positive Interpretation of the Analects[M]. China Three Gorges Publishing House, May 2007 Edition

[2] Huang Baolin. Analysis of Confucius Education Thoughts[J]. Journal of Zhengzhou Railway Vocational and Technical College, 2010

[3] Tian Fangyuan. The Enlightenment of Moral Education Thought in The Analects of Confucius on Contemporary College Students' Moral Education[J]. Master's Thesis of Shenyang Normal University, 2012.

[4] Liu Ying. Confucius' Moral Education Thought and Its Enlightenment[J]. Chinese Education Journal, 2003.

[5] Liu Dejiang. Popular interpretation of Confucius wisdom [M]. China Three Gorges Publishing House, 2007.

[6] Guo Dan. "Zhongyong" "Neutralization" Thought and Confucian Education". Master's thesis of Shandong Normal University. 2016. 